UDC 616-092.9: 613.2.099: 615.[918+919]

DOI: 10.21668/health.risk/2018.3.12.eng

Read online

\title{
TOXICITY OF YESSOTOXIN IN EXPERIMENT IN VIVO
}

\section{O.V. Bagryantseva ${ }^{1,2}$, I.V. Gmoshinskii ${ }^{1}$, A.D. Evstratova ${ }^{1}$, E.N. Trushina ${ }^{1}$, O.K. Mustafina ${ }^{1}$, Kh.S. Soto ${ }^{1}$, V.A. Shipelin ${ }^{1}$, A.A. Shumakova ${ }^{1}$, A.D. Panova ${ }^{2}$, S.A. Khotimchenko ${ }^{1,2}$}

${ }^{1}$ Federal Research Center for Nutrition, Biotechnology and Food Safety, 2/14 Ust'inskiy lane, Moscow, 109240, Russian Federation

${ }^{2}$ I.M. Sechenov First Moscow State Medical University, Build. 2, 8 Trubetskaya Str., Moscow, 119991, Russian Federation

Yessotoxin (YTX) is a polyether. There are more than 90 known derivatives of yessotoxin. YTX was excluded from diarrhea toxins group as it, unlike okadaic acid, doesn't cause diarrhea. YTX chemical structure is similar to that of brevetoxins and ciguatoxins that influence functioning of calcium-sodium pump and trans-membrane ion channels. So, YTX can exert influence on functioning of all the organs and systems in a body. YTX is known to promote apoptosis in the cerebral tissues. Average lethal dose $L D_{50}$ for YTX and its analogues varied from $100 \mu \mathrm{g} / \mathrm{kg}$ to $500-750 \mu \mathrm{g} / \mathrm{kg}$; the figures were obtained in various experiments performed on mice. Safe YTX level for acute impact (acute reference dose) amounts to $25 \mu \mathrm{M} / \mathrm{kg}$ of body weight.

Nowadays toxicity parameters for YTX and some of its analogues are determined; its basic action mechanisms and a role it plays in promoting apoptosis are well-known. In spite of more and more data on biological effects produced by YTX on a warm-blooded organism, experts are still unable to describe its action mechanisms precisely. Our research goal was to examine YTX toxicity in experiments in vivo in doses that were lower than the detected acute reference dose.

The experiment was performed on 72 male Wistar rats with initial body weight being equal to $100 \pm 102$. Animals were given dry balanced feedstuff produced by "Laboratortakorm" LLC (Russia) and had free access to it. We used YTX preparation produced by "National Research Council Canada" (Canada) in our experiment; the preparation was a methanol solution (YTX content was equal to $4.3 \mu \mathrm{mol}$ ). We determined mass of internal organs, biochemical and hematological blood parameters, apoptosis of brain cells, malonic dialdehyde level in the brain and reduced glutathione in the liver.

We showed that YTX doses $(2,8$ and $12 \mu \mathrm{M} / \mathrm{kg})$ lower than ARfD $=2 \mu \mathrm{M} / \mathrm{kg}$ can exert toxic impacts on a warmblooded organism. The obtain data prove it is necessary to additionally assess risks of an increase in maximum permissible YTX contents in shellfish from $1 \mathrm{mg} / \mathrm{kg}$ to $3.75 \mathrm{mg} / \mathrm{kg}$. level.

Key words: yessotoxin, action mechanisms, in vivo, biological markers, toxicity, risk assessment, permissible

(C) Bagryantseva O.V., Gmoshinskii I.V., Evstratova A.D., Trushina E.N., Mustafina O.K., Soto Kh.S., Shipelin V.A., Shumakova A.A., Panova A.D., Khotimchenko S.A., 2018

Olga V. Bagryantseva - Doctor of Biological Sciences, Leading Researcher at Laboratory for Food Toxicology and Nanotechnologies Safety Assessment (e-mail: olga_bagryanseva@mail.ru; tel.: +7 (495) 698-54-05).

Ivan V. Gmoshinskii - Doctor of Biological Sciences, Leading Researcher at Laboratory for Food Toxicology and Nanotechnologies Safety Assessment (e-mail: gmosh@ion.ru; tel.: +7 (495) 698-53-71).

Anna D. Evstratova - Research Assistant at Laboratory for Food Toxicology and Nanotechnologies Safety Assessment (e-mail: anya.evstratova@mail.ru; tel.: +7 (495) 698-53-68).

Eleonora N. Trushina - Candidate of Medical Sciences, Head of Immunology Laboratory (e-mail: trushina@ion.ru; tel.: +7 (495) 698-53-45).

Oksana K. Mustafina - Candidate of Medical Sciences, Senior Researcher at Immunology Laboratory (e-mail: mustafina@ion.ru; tel.: +7 (495) 698-53-45).

Selada Kh. Soto - Candidate of Medical Sciences, Senior Researcher at Laboratory for Metabolic and Proteomic Analysis (e-mail: jsotoc@mail.ru; tel.: +7 (495) 698-54-07).

Vladimir A. Shipelin - Candidate of Medical Sciences, Senior Researcher at Laboratory for Food Toxicology and Nanotechnologies Safety Assessment (e-mail: v.shipelin@yandex.ru; tel.: +7 (495) 698-63-71).

Antonina A. Shumakova - Researcher at Laboratory for Food Toxicology and Nanotechnologies Safety Assessment (e-mail: antonina sh@list.ru; tel.: +7 (495) 698-53-68).

Sergei A. Khotimchenko - Doctor of Medical Sciences, Professor, Head at Laboratory for Food Toxicology and Nanotechnologies Safety Assessment (e-mail: hotimchenko@ion.ru; tel.: +7 (495) 698-52-35). 
Yessotoxin (YTX) is a polyether; it consists of 11 adjacent ether rings, unsaturated side chain and two sulfate ethers. There are more than 90 derivatives of yessotoxin. It was first extracted in 1986 in Japan out of scallops Patinopectenyessoensis. YTX is produced by algae, namely dinoflagellates Protoceratiumreticulatum and Gonyaulaxspinifera. YTX was excluded out of diarrhea toxins group (okadaic acid and its analogues, "DSP toxins") as it, unlike okadaic acid, doesn't cause diarrhea. However YTX and its analogues are often extracted together with diarrhea toxins and give positive results in biological tests aimed at detecting diarrhea poisons in shellfish [1].

YTX chemical structure is similar to those of brevetoxins and siguatoxins that exert their impacts on functioning of calcium-sodium pump and transmembrane ion channels. Mechanism that activates phosphodiesterase with yessotoxin includes an initial increase in calcium contained in cell cytosol and available to calcium-dependent I type phoisphodiesterase; then intracellular concentration of cyclic adenosine monophosphate goes down $[2,3]$.

YTX makes for an increase in activity of caspase 3 and 7 in HeLa cells. It stimulates greater mitochondrial membranes penetrability in livers of rats and causes disorders in cytoskeleton of cerebellum neurons cells and their consequent apoptosis; it makes for disorders in intercellular adhesion and it, in its turn, can be a possible reason for Alzheimer disease occurrence [4-7]; it influences the immune system as it makes for higher cytokines quantity due to greater expressions of genes that code them [8]. YTX induces a mitotic disaster and genetic changes that can be interesting for studying ways of control over tumor processes development [9].

Average lethal dose $\mathrm{LD}_{50}$ of YTX and its analogues was determined in various experiments on mice and varied from $100 \mu \mathrm{g} / \mathrm{kg}$ to $500-750 \mu \mathrm{g} / \mathrm{kg}$ [6]. In our opinion, these different toxicity values for various yessotoxins depend on peculiarities of their chemical structure. A safe dose under acute exposure to YTX (Acute Reference Dose) amounts to $25 \mu \mathrm{M} / \mathrm{kg}$ of a body weight. There are practically no data on YTX toxicity for other animals $[3,6$, 10]. In 2004 the Order by the European Union No. $853 / 2004$ fixed a safe concentration of yessotoxins in shellfish; it amounted to $1 \mathrm{mg} / \mathrm{kg}$ [11]. But still, analysis of yessotoxins content in shellfish meat revealed that yessotoxins contents didn't exceed $3.75 \mathrm{mg}$ of yessotoxins equivalents / $\mathrm{kg}$ of shellfish meat in any of examined samples [6]. Results of this analysis gave grounds for a new maximum permissible concentration of yessotoxins in shellfish, $3.75 \mathrm{mg} / \mathrm{kg}$ [12].

Therefore, nowadays there are toxicity parameters set for YTX and some of its analogues; specific molecules that are primary targets for its effects are determined as well as its role as a promoter of apoptosis; maximum permissible concentration of yessotoxin in shellfish is fixed. However, in spite of more and more data on biological effects produced by YTX on a warm-blooded organism, its exact action mechanism hasn't been determined yet.

Our research goal was to examine YTX toxicity in experiments in vivo in doses lower than the fixed acute reference dose.

Data and methods. Our experiment was performed on 72 male Wistar rats with initial body weight being equal to $100 \pm 10 \mathrm{~g}$. The animals were provided by the "Russian Scientific Center for Biomedical Technologies", "Stolbovaya" subsidiary. The animals were given dry balanced feedstuff produced by "Laboratorkorm" LLC (Russia) and had free access to it. The rats were kept in cages made of polycarbonate, 2-3 animals in each, their lighting regime being 12/12 hours, and the temperature being $21 \pm 1 \mathrm{oC}$. All the rats were randomly divided into 12 groups, 6 animals in each; initial body weight in groups was the same $(\mathrm{p}>0.1$ ANOVA). All the experimental work with animals was performed in compliance with the requirements to good laboratory practice fixed in Russia ${ }^{1}$.

We used a preparation of YTX produced by "National Research Council Canada" (Canada) in our experiment; the preparation was a methanol solution (YTX content was equal to $4.3 \mu \mathrm{mol}$ ). Directly before the experiment methanol was

${ }^{1}$ On approval of rules for good laboratory practice: the Order by the RF Public Healthcare Ministry No. 193 dated April 01, 2016. Pharmakopea.rf. Available at: http://pharmacopoeia.ru/wp-content/uploads/2016/08/PrikazMinzdrava-199n-ot-01.04.2016-Ob-utverzhdenii-Pravil-nadlezhashhej-Laboratornoj-praktiki.pdf (date of visit April 16, 2018)

${ }^{2}$ State Standard 5962-2013. Ethanol rectified out of food raw materials. technical conditions. KODEKS: an electronic fund of legal and reference documentation. Available at: http://docs.cntd.ru/document/1200103298 (date of visit: April 16, 2018) 
removed out of the preparation via vacuum evaporation under a temperature that didn't exceed $+20 \mathrm{oC}$; the process was not to last longer than 4 hours. A dry residue was then dissolved again in 96\% ethanol solution according to the State Standard 5962-2013 ${ }^{2}$. To obtain working dilutions of the toxin, we diluted aliquots of YTX ethanol solution with a sterile apyrogenic solution of 0.15 $\mathrm{M} \mathrm{NaCl}$; the obtained solutions had the following concentrations: $2 \mu \mathrm{M} / \mathrm{kg}$ (groups 2,6 , and 10 ); 8 $\mu \mathrm{M} / \mathrm{kg}$ (groups 3, 7, and 11); and $12 \mu \mathrm{M} / \mathrm{kg}$ (groups 4, 8, and 12): $1 \mathrm{~mol}$ of YTX=1187.32 g. All the experimental doses were lower than the fixed acute reference dose (ARfD) of YTX that was equal to $25 \mu \mathrm{M} / \mathrm{kg}$ of body weight.

YTX-containing solutions were introduced into rats from the above-mentioned test groups; there was a single intraperitoneal introduction in a dose equal to $1 \mathrm{ml} / \mathrm{kg}$ of a body weight. Animals from the reference groups (1, 5 and 9) were given saline in the same manner and quantity.

Animals were taken out of the experiment 6 hours (groups 1-4), 24 hours (groups 5-8), and 168 hours (groups 9-12) after the preparation had been introduced; they were taken out of the experiment via decapitation under ether anesthesia. Blood was collected with anticoagulant (tripotassium EDTA); samples of brains tissues were taken to determine apoptosis and malonic dialdehyde concentration; samples of liver tissues were taken to determine glutathione contents. Masses of internal organs (liver, kidneys, spleen, lungs, heart, thymus, adrenals, gonads, and brains) were determined with an electronic balance with inaccuracy being equal to $\pm 0.01 \mathrm{~g}$.

We determined biochemical parameters of blood serum with "Konelab 20i" biochemical analyzer (Finland). Malonic dialdehyde contents in the brain were detected via an optical technique with 2-thiobarbituric acid and chromogen level measuring with maximum absorption in red visible spectrum with wavelength being equal to $532 \mathrm{~nm}$ [13]. We determined reduced glutathione contents in rats' livers with spectrophotometry as per [14].

Hematologic parameters were determined in whole blood according to conventional techniques with a "Coulter AC TTM 5 diff OV" hematologic analyzer ("Beckman Coulter", the USA) with a regents kit ("Beckman Coulter", France). We examined brain cells apoptosis with "FC 500" flow cytofluorimeter ("Beckman Coulter International S.A.", Austria) with a painting procedure applied for brain neurons; they were painted in a suspension with the following fluorescent reagents: FITC-annexin V and 7-aminoactinomycin (7AAD) [15].

We processed the results statistically via determining sample average, standards error, a possibility of a zero hypothesis on a coincidence of compared samplings distributions as per Student test, Mann-Whitney test, and ANOVA. Discrepancies were considered to be authentic at significance level $\mathrm{p}<0.05$.

Results and discussion. YTX introduction in all the above-mentioned doses didn't result in any signs of diseases in all the test groups. We didn't detect any authentic changes in body masses of animals or in masses of their gonads, adrenals, or brains. However, we detected an authentic decrease $(p<0.05)$ in masses of spleen, lungs, and thymus (in \% of a body weight) during the whole experiment. Masses of heart, kidneys, and liver also tended to go down (Figure 1).

Determination of hematologic parameters 168 hours after YTX had been introduced revealed a decrease in lymphocytes contents $(p<0.05)$ and a trend for an increase in neutrophils quantity in blood serum of the experimental animals. We revealed that when the toxin was introduced in all the experimental doses, it caused an increase in leucocytes contents during the whole experiment; it was proved by discrepancies in the values obtained in most experimental groups against the reference one $(\mathrm{p}<0.05)($ Table 1$)$.

Despite all changes in blood composition parameters didn't have any apparent dosedepending nature, the obtained data are an evidence that YTX can possibly exert negative impacts when it is introduced intraperitoneally in doses that, according to available data, are not supposed to be toxic for experimental animals.

Urea contents in blood serum went down non-monotonously after introduction of all the experimental doses in comparison with the reference groups during the whole experiment. We detected an increased creatinine content 6 hours after the toxin introduction; the parameter decreased 168 hours after the introduction. We revealed a trend for a decrease in crude protein contents in all the test groups and a decrease in alanine aminotransferase (ALAT) in blood plasma 6 and 24 hours after the toxin introduction. The obtained data indicate that YTX influences protein metabolism and that catabolic processes induced by the toxin prevail in bodies of warm-blooded animals (Table 2). 
Spleen

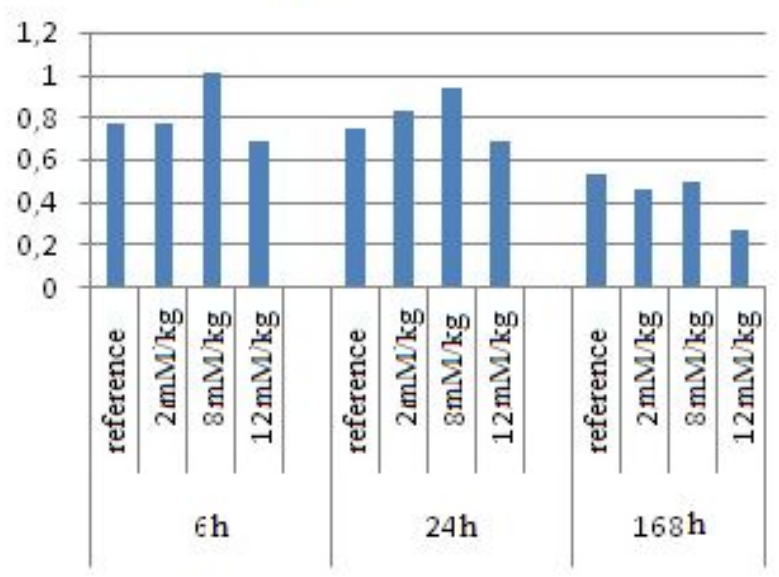

Lungs

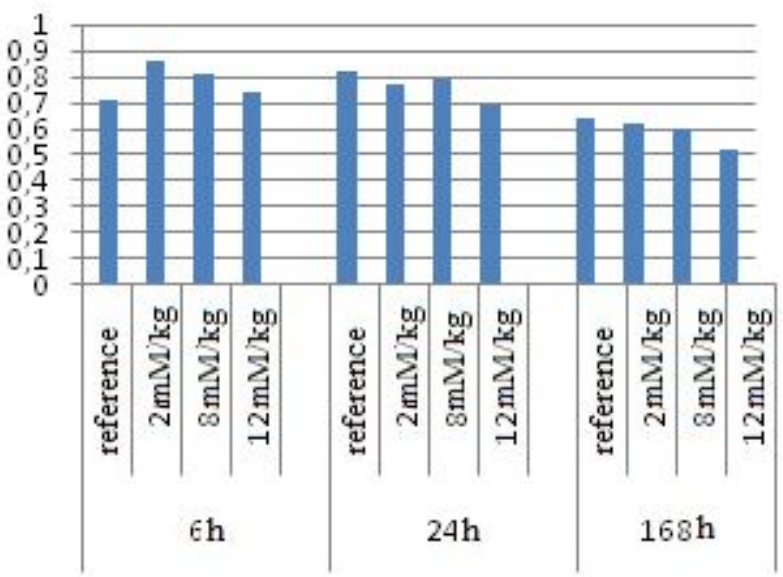

Thymus

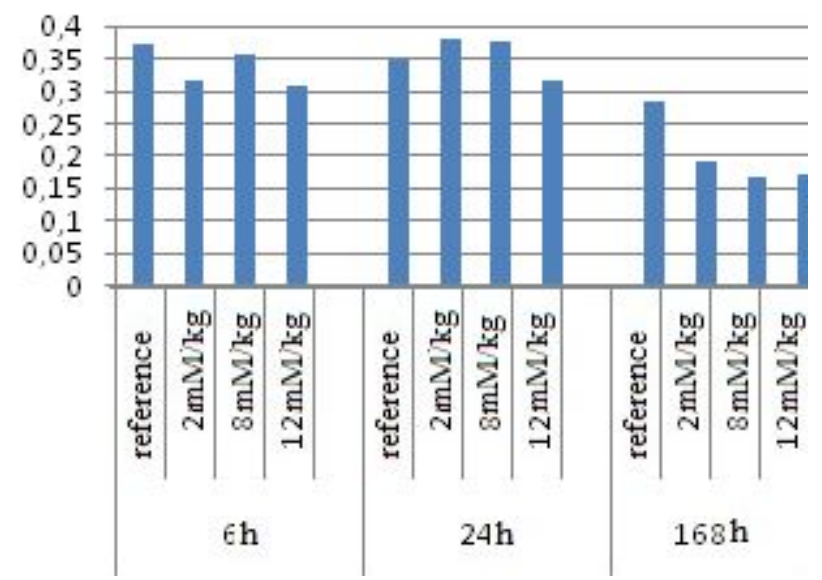

Heart

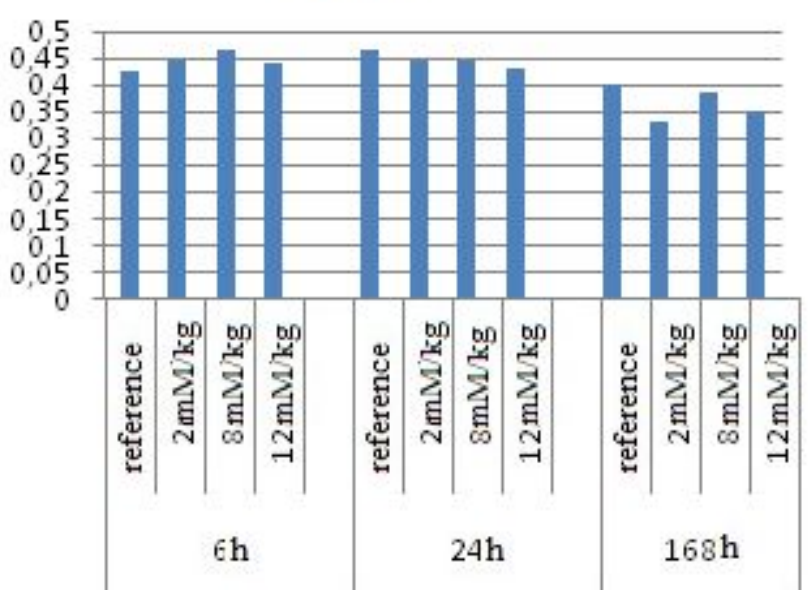

Kidneys

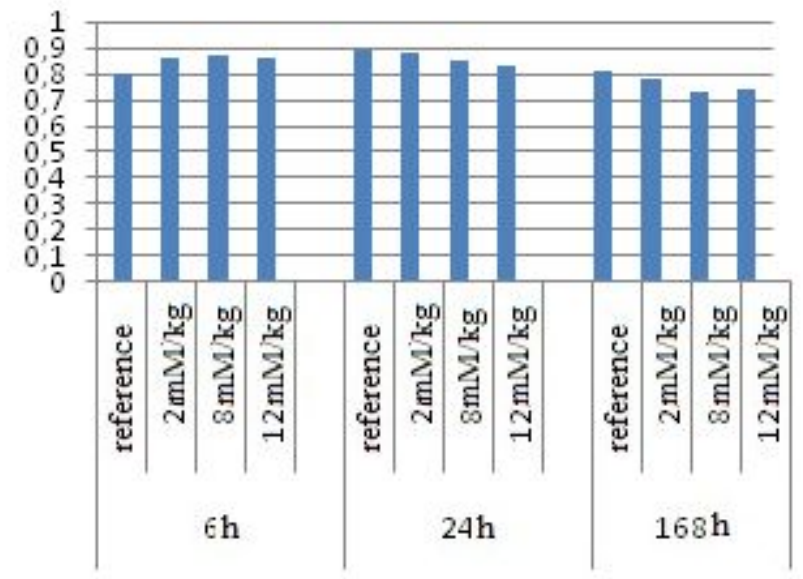

Liver

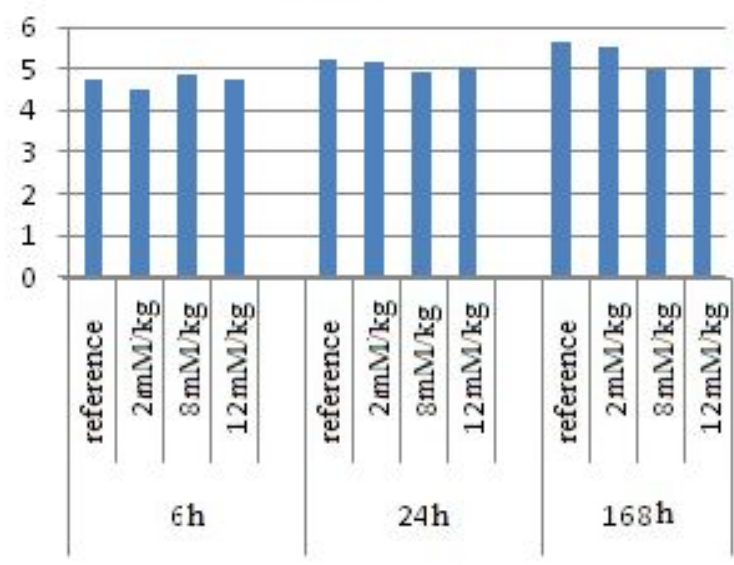

Figure 1.Dynamics of changes in masses of internal organs (in $\%$ of rats' body weight). $\underline{X \text {-axis }}$ shows doses and period of YTX introduction; $\underline{Y}$ axis shows a mass of an organ in $\%$ of a total body weight. There were 6 animals in each group. 
Table 1

Hematologic parameters (erythrocytes and leukocytes), $\mathrm{M} \pm \mathrm{m}$ of rats 6, 24 and 168 hours after YTX introduction (6 animals in each group)

\begin{tabular}{|c|c|c|c|c|c|c|c|c|}
\hline \begin{tabular}{|c|} 
Group \\
$\mathrm{s}$
\end{tabular} & \begin{tabular}{|c|} 
YTX \\
dose, \\
$\mu \mathrm{g} / \mathrm{kg}$ \\
$(\mathrm{mM} / \mathrm{kg})$
\end{tabular} & $\begin{array}{l}\text { Period after } \\
\text { the toxin } \\
\text { introduc- } \\
\text { tion, } \mathrm{h}\end{array}$ & $\begin{array}{l}\text { Average content } \\
\text { of } \mathrm{Hb} \text { in erythro- } \\
\text { cyte, pg }\end{array}$ & $\begin{array}{c}\text { Average } \mathrm{Hb} \\
\text { concentration in } \\
\text { erythrocyte, } \mathrm{g} / \mathrm{l}\end{array}$ & $\begin{array}{c}\text { Leucocytes } \\
\text {, } \\
10^{9} 1\end{array}$ & $\begin{array}{l}\text { Nuetro- } \\
\text { phils, \% }\end{array}$ & $\begin{array}{l}\text { Lympho- } \\
\text { cytes, \% }\end{array}$ & $\begin{array}{c}\text { Monocytes } \\
, \%\end{array}$ \\
\hline 1 & reference & \multirow{4}{*}{6} & $20,2 \pm 0,4$ & $326,5 \pm 1,3$ & $8,9 \pm 1,0$ & $24,1 \pm 2,3$ & $61,8 \pm 2,8$ & $12,6 \pm 1,6$ \\
\hline 2 & 2 & & $20,4 \pm 1,3$ & $326,3 \pm 1,8$ & $14,0 \pm 3,2$ & $25,8 \pm 3$ & $63,7 \pm 3,0$ & $9,2 \pm 0,8$ \\
\hline 3 & 8 & & $21,0 \pm 0,5$ & $322,0 \pm 3,4$ & $10,0 \pm 2,6$ & $19,9 \pm 2,8$ & $65,8 \pm 3,4$ & $11,9 \pm 0,6$ \\
\hline 4 & 12 & & $19,5 \pm 0,4 *$ & $321,6 \pm 2,8$ & $10,7 \pm 1,5^{*}$ & $25,2 \pm 1,8$ & $62,6 \pm 2,5$ & $10,9 \pm 0,8^{*}$ \\
\hline 5 & reference & \multirow{4}{*}{24} & $19,7 \pm 0,3$ & $325,3 \pm 2,4$ & $11,2 \pm 1,5$ & $23,5 \pm 3,0$ & $60,8 \pm 2,6$ & $12,6 \pm 1,3$ \\
\hline 6 & 2 & & $20,7 \pm 0,3$ & $324,2 \pm 3,6$ & $13,9 \pm 3,6^{*}$ & $26,8 \pm 4,6$ & $60,4 \pm 6,1$ & $11,7 \pm 1,7$ \\
\hline 7 & 8 & & $20,8 \pm 0,7$ & $323,8 \pm 3,1$ & $13,3 \pm 2,7^{*}$ & $26,3 \pm 4,6$ & $61,6 \pm 4,5$ & $11,6 \pm 0,7$ \\
\hline 8 & 12 & & $20,3 \pm 0,3$ & $326,0 \pm 3,7$ & $10,5 \pm 1,1$ & $23,9 \pm 3,0$ & $62,6 \pm 3,2$ & $12,0 \pm 1,3$ \\
\hline 9 & reference & \multirow{4}{*}{168} & $19,5 \pm 0,2$ & $330,5 \pm 3,6$ & $8,4 \pm 0,8$ & $27,2 \pm 2,3$ & $57,6 \pm 2,3 * *$ & $13,0 \pm 1,9$ \\
\hline 10 & 2 & & $19,7 \pm 0,3$ & $331,8 \pm 2,0$ & $10,3 \pm 1,3^{*}$ & $35,6 \pm 2,6^{*}$ & $50,7 \pm 2,4 * *$ & $11,9 \pm 1,2$ \\
\hline 11 & 8 & & $20,1 \pm 0,3$ & $328,8 \pm 2,7$ & $13,7 \pm 1,9^{*}$ & $29,3 \pm 4,7$ & $59,2 \pm 4,9 * *$ & $10,0 \pm 1,4$ \\
\hline 12 & 12 & & $19,4 \pm 0,3$ & $329,8 \pm 2,2$ & $6,4 \pm 0,8$ & $29,4 \pm 2,1$ & $54,8 \pm 1,0 * *$ & $13,8 \pm 1,9$ \\
\hline
\end{tabular}

Note: * means authentic discrepancies from the reference group for this time period, $\mathrm{p}<0.05$, Student Ttest and/or Mann-Whitney test

** means a discrepancy between groups ( 6 and 168 hours after YTX introduction) is authentic for this criterion, $\mathrm{p}<0.05$, Student T-test and/or Mann-Whitney test

Table 2

Biochemical parameters of rats' blood plasma, $\mathrm{M} \pm \mathrm{m}, 6,24$ and 168 hours after YTX introduction (6 animals in each group)

\begin{tabular}{|c|c|c|c|c|c|c|c|c|c|c|}
\hline Groups & $\begin{array}{c}\text { YTX } \\
\text { dose, } \\
\mu \mathrm{g} / \mathrm{kg} \\
(\mathrm{mM} / \mathrm{kg})\end{array}$ & $\begin{array}{c}\text { Period after } \\
\text { the toxin } \\
\text { introduction, } \\
\mathrm{h}\end{array}$ & $\begin{array}{c}\text { Cholesterol, } \\
\mathrm{mmol} / \mathrm{l}\end{array}$ & $\begin{array}{c}\text { Triglycerides, } \\
\mathrm{mmol} / \mathrm{l}\end{array}$ & \begin{tabular}{|c|}
$\mathrm{ALT}$, \\
uints/ml
\end{tabular} & $\begin{array}{c}\text { AST, } \\
\text { units/ml }\end{array}$ & $\begin{array}{c}\text { Crude } \\
\text { protein, } \\
\mathrm{g} / \mathrm{l}\end{array}$ & $\begin{array}{c}\text { Creatinine, } \\
\mu \mathrm{mol} / \mathrm{l}\end{array}$ & $\begin{array}{l}\text { Urea, } \\
\mathrm{mmol} / \mathrm{l}\end{array}$ & $\begin{array}{c}\text { Uric } \\
\text { acid, } \\
\mu \mathrm{mol} / 1\end{array}$ \\
\hline 1 & reference & \multirow{4}{*}{6} & $1,29 \pm 0,20$ & $1,01 \pm 0,21$ & $\begin{array}{c}103,26 \pm \\
11,25\end{array}$ & $\begin{array}{c}184,94 \pm \\
19,49\end{array}$ & $62,59 \pm 2,93$ & $36,15 \pm 0,85$ & $9,93 \pm 0,87$ & $\begin{array}{c}213,05 \pm \\
13,48\end{array}$ \\
\hline 2 & 2 & & $2,29 \pm 0,07^{*}$ & $1,08 \pm 0,10$ & $\begin{array}{c}146,42 \pm \\
14,96^{*}\end{array}$ & $\begin{array}{c}113,64 \pm \\
41,35\end{array}$ & $58,58 \pm 0,99$ & $44,91 \pm 1,24 *$ & $\begin{array}{c}6,28 \pm \\
0,16^{*}\end{array}$ & $\begin{array}{c}222,70 \pm \\
21,37\end{array}$ \\
\hline 3 & 8 & & $2,22 \pm 0,08^{*}$ & $0,87 \pm 0,10$ & $\begin{array}{c}153,35 \pm \\
15,92^{*} \\
\end{array}$ & $\begin{array}{c}152,75 \pm \\
59,19 \\
\end{array}$ & $\begin{array}{c}56,87 \pm \\
1,32 * \\
\end{array}$ & $3,55^{*}$ & $\begin{array}{c}5,66 \pm \\
0,75^{*} \\
\end{array}$ & $\begin{array}{c}243,48 \pm \\
24,27 \\
\end{array}$ \\
\hline 4 & 12 & & $1,96 \pm 0,25^{*}$ & $0,74 \pm 0,11^{*}$ & $\begin{array}{c}140,95 \pm \\
7,39 * \\
\end{array}$ & $\begin{array}{c}160,16 \pm \\
42,13\end{array}$ & $59,54 \pm 1,48$ & $40,25 \pm 0,75^{*}$ & $\begin{array}{l}5,95 \pm \\
0,49^{*} \\
\end{array}$ & $\begin{array}{c}215,21 \pm \\
29,85\end{array}$ \\
\hline 5 & reference & \multirow{4}{*}{24} & $1,41+0,16$ & $1,01 \pm 0,25$ & $\begin{array}{c}101,29 \pm \\
9,04 \\
\end{array}$ & $\begin{array}{c}182,80 \pm \\
36,41 \\
\end{array}$ & $62,25 \pm 3,78$ & $37,66 \pm 0,95$ & $\begin{array}{c}10,10 \pm \\
1,25 \\
\end{array}$ & $\begin{array}{c}195,11 \pm \\
27,61 \\
\end{array}$ \\
\hline 6 & 2 & & $2,08 \pm 0,15^{*}$ & $0,76 \pm 0,08 *$ & $\begin{array}{c}137,97 \pm \\
16,01 * \\
\end{array}$ & $\begin{array}{c}300,23 \pm \\
30,72 \\
\end{array}$ & $\begin{array}{c}57,53 \pm \\
1,20 * \\
\end{array}$ & $36,36 \pm 0,60$ & $\begin{array}{l}5,82 \pm \\
0,17^{*} \\
\end{array}$ & $\begin{array}{c}108,47 \pm \\
11,51 \\
\end{array}$ \\
\hline 7 & 8 & & $1,99 \pm 0,11^{*}$ & $0,89 \pm 0,08$ & $\begin{array}{c}104,11 \pm \\
7,05 \\
\end{array}$ & $\begin{array}{c}240,16 \pm \\
36,03 \\
\end{array}$ & $\begin{array}{c}54,97 \pm \\
1,54^{*} \\
\end{array}$ & $37,76 \pm 0,26$ & $\begin{array}{l}7,73 \pm \\
0,30^{*}\end{array}$ & $\begin{array}{c}171,84 \pm \\
22,86 \\
\end{array}$ \\
\hline 8 & 12 & & $2,00 \pm 0,17^{*}$ & $0,81 \pm 0,07$ & $\begin{array}{c}146,54 \pm \\
19,2^{*} \\
\end{array}$ & $\begin{array}{c}203,70 \pm \\
44,27 \\
\end{array}$ & $58,91 \pm 1,16$ & $40,65 \pm 1,44 *$ & $\begin{array}{l}7,79 \pm \\
0,31^{*} \\
\end{array}$ & $\begin{array}{c}191,54 \pm \\
35,40 \\
\end{array}$ \\
\hline 9 & reference & \multirow{4}{*}{168} & $1,94 \pm 0,19$ & $0,79 \pm 0,13$ & $\begin{array}{c}106,56 \pm \\
12,33\end{array}$ & $\begin{array}{c}280,39 \pm \\
16,19\end{array}$ & $63,72 \pm 3,92$ & $42,35 \pm 1,72$ & $9,66 \pm 0,51$ & $\begin{array}{c}183,68 \pm \\
9,71\end{array}$ \\
\hline 10 & 2 & & $1,83 \pm 0,09$ & $0,71 \pm 0,05$ & $91,49 \pm 8,58$ & $\begin{array}{c}206,67 \pm \\
23,28\end{array}$ & $\begin{array}{c}55,38 \pm \\
0,97^{*}\end{array}$ & $34,40 \pm 1,39 *$ & $\begin{array}{c}7,69 \pm \\
0,59^{*}\end{array}$ & $\begin{array}{c}174,08 \pm \\
27,71\end{array}$ \\
\hline 11 & 8 & & $2,30 \pm 0,14 *$ & $0,82 \pm 0,04$ & $\begin{array}{c}116,87 \pm \\
14,46\end{array}$ & $\begin{array}{c}187,33 \pm \\
48,06\end{array}$ & $59,25 \pm 3,04$ & $35,32 \pm 2,05 *$ & $\begin{array}{l}7,26 \pm \\
0,55^{*}\end{array}$ & $\begin{array}{c}167,79 \pm \\
53,90\end{array}$ \\
\hline 12 & 12 & & $1,21 \pm 0,04$ & $1,24 \pm 0,04$ & $\begin{array}{c}110,77 \pm \\
8,21\end{array}$ & $\begin{array}{c}86,57 \pm \\
29,44\end{array}$ & $59,76 \pm 1,79$ & $36,76 \pm 0,71 *$ & $9,81 \pm 0,62$ & $\begin{array}{c}198,33 \pm \\
24,56\end{array}$ \\
\hline
\end{tabular}

Note : * means authentic discrepancies from the reference group for this time period, $\mathrm{p}<0.05$, Student $\mathrm{T}$ test and/or Mann-Whitney test 
Triglycerides contents tended to decrease and there was an authentic increase in cholesterol content in blood serum 6 and 24 hours after YTX introduction (Table 2). This dynamics is an evidence that YTX exerts its influence on lipid metabolism and that there is a possible induction of an inflammatory process caused by the toxin impacts; all the above-mentioned goes well in line with the available data on YTX action mechanism $[5,6]$.

We were the first to detect an authentic $(\mathrm{p}<0.05)$ dose-dependent increase in malonic dialdehyde (MDA) content in brain tissues 168 hours after YTX introduction (Figure 2) and a trend for an increase in reduced glutathione content in liver tissues (Figure 3). Besides, we revealed an authentic $(\mathrm{p}<0.1)$ dose-dependent increase in the quantity of brain neurons with early apoptosis $(2.3 \%$ of cells when a dose equal to $2 \mathrm{mM} / \mathrm{kg}$ was introduced; $3.02 \%$ of cells when a dose equal to 12 $\mathrm{mM} / \mathrm{kg}$ was introduced; $1,78 \%$ of overall cells number in reference groups) and a decrease in late apoptosis activity (from $0.367 \%$ under a dose equal to $2 \mathrm{mM} / \mathrm{kg}$ to $0.180 \%$ under a dose equal to 12 $\mathrm{mM} / \mathrm{kg} ; 0.45 \%$ of the overall cells number in reference groups) that was observed during the whole experiment (Figure 4).

The obtained data supplement those already available in literature; all the data prove that YTX induces catabolic processes. These processes become apparent via activation of free radical oxidation and brain cells apoptosis $[3,6,10]$. We were the first to show that YTX doses equal to $2 \mu \mathrm{M} / \mathrm{kg}$, $8 \mu \mathrm{M} / \mathrm{kg}$, and $12 \mu \mathrm{M} / \mathrm{kg}$ could produce toxic effects on a warm-blooded organism.

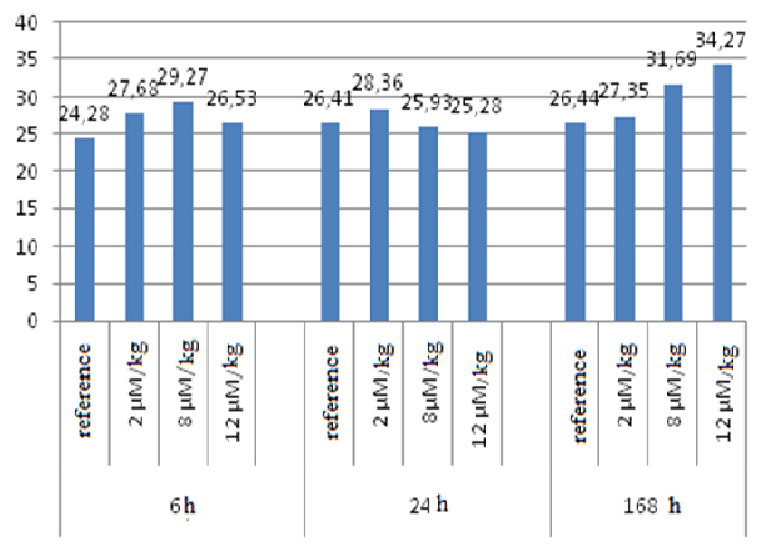

Figure 2. MDA contents in brain tissues $X$ axis shows YTX doses; Y axis shows MDA concentration in the brain, $\mathrm{nmol} / \mathrm{g}$ of tissue.

There were 6 animals in each group

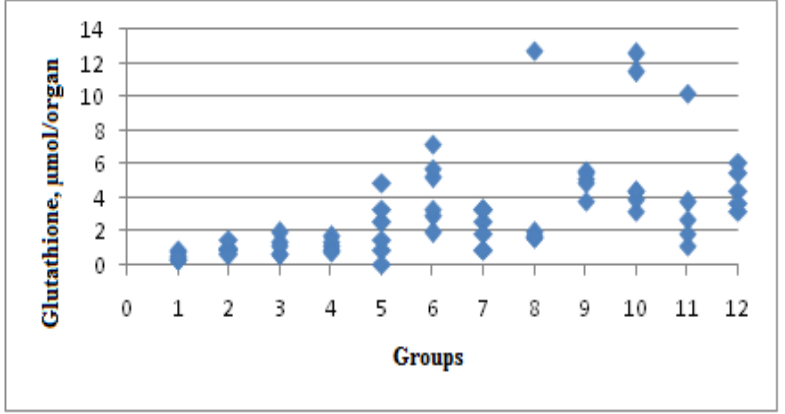

Figure 3. Reduced glutathione contents in livers of rats

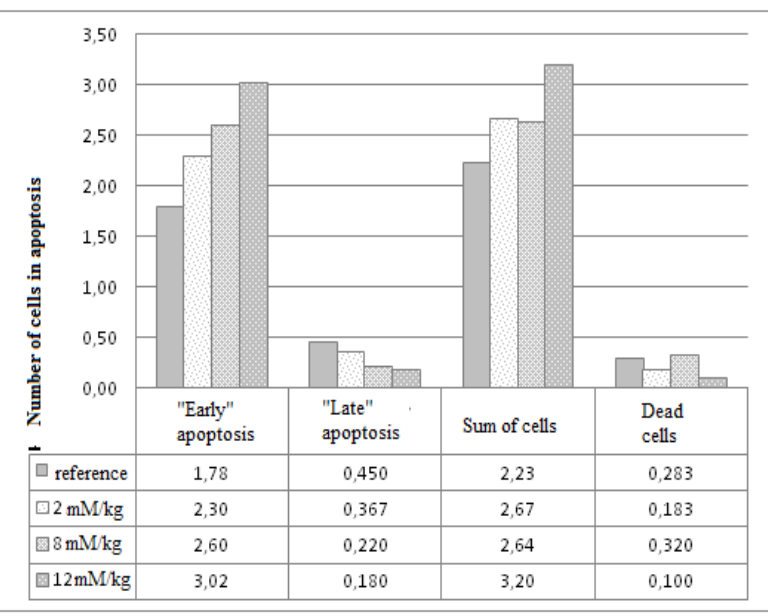

Figure 4. Parameters of apoptosis in brain tissues (in $\%$ of overall number of neurons in a visual field) after YTX introduction. The obtained values of cells quantities for "early" and "late" apoptosis are authentic and dose-dependent changes in them go in opposite directions $(\mathrm{p}<0.1)$

All the tested doses were lower than the fixed acute reference dose for YTX (ARfD $=25$ $\mu \mathrm{m} / \mathrm{kg}$ of a body weight). A dose equal to $2 \mu \mathrm{M} / \mathrm{kg}$ corresponds to the permissible toxin contents in shellfish, or $2.37 \mathrm{mg} / \mathrm{kg}$. The obtained data, as well as data published in scientific works on possible toxic effects produced by YTX in doses lower than ARfD, prove that an increase in maximum permissible concentration of yessotoxins in shellfish from $1 \mathrm{mg} / \mathrm{kg}$ to $3.75 \mathrm{mg} / \mathrm{kg}$ was not well grounded.

Conclusion. Our research revealed that yessotoxin produced toxic effects when introduced intraperitoneally during the whole experiment and in all the tested doses, $2 \mu \mathrm{M} / \mathrm{kg}, 8 \mu \mathrm{M} / \mathrm{kg}$, and 12 $\mu \mathrm{M} / \mathrm{kg}$. All the tested doses were lower than the fixed acute reference dose for YTX (ARfD), equal to $25 \mu \mathrm{M} / \mathrm{kg}$ of body weight. The toxic effects became apparent via:

- an authentic decrease in masses of spleen, lungs, and thymus (in \% of a body weight) during 
the whole experiment and trends for a decrease in masses of heart, kidneys, and liver;

- in more intense protein catabolism (a decrease in protein contends, higher creatinine, uric acid, and ALT concentration in blood plasma), and lipid catabolism (a trend for a decrease in triglycerides contents and an authentic increase in cholesterol contents in blood plasma) in all the experimental groups;

- in more intense free radical oxidation in the brain that became apparent via a dosedependent growth in malonic dialdehyde contents 168 hours after the toxin introduction;

- in more intense processes of early apoptosis and a decrease in late apoptosis in brain tissues.
The obtained data indicate it is necessary to perform additional assessments of a risk related to an increase in maximum permissible concentration of yessotoxins in shellfish from $1 \mathrm{mg} / \mathrm{kg}$ to $3.75 \mathrm{mg} / \mathrm{kg}$.

Funding. The experiments were performed due to funds provided by a grant for accomplishing a task set by the governmental authorities within Fundamental Scientific Research Program (FASO Russia, subject No. 0529-20140044).

Conflict of interest. The authors state there is no conflict of interests

\section{References}

1. Paz B., Daranas A.H., Norte M., Riobó P., Franco J.M., Fernández J.J. Yessotoxins, a Group of Marine Polyether Toxins: an Overview. Mar. Drugs., 2008, vol. 6, pp. 73-102. DOI: $10.3390 / \mathrm{md} 20080005$

2. Alfonso A., de la Rosa L., Vieytes M.R., Yasumoto T., Botana L.M.Yessotoxin, a novel phycotoxin, activates phosphodiesterase activity. Effect of yessotoxin on cAMP levels in human lymphocytes. Biochem. Pharmacol., 2003, vol. 65, no. 2, pp. 193-208.

3. Report of the Joint FAO/IOC/WHO ad hoc Expert Consultation on Biotoxins in Bivalve Molluscs. Oslo, Norway,

26-30 September 2004. Short Summary.UNESCO, 2005, 8 p. Available at: http://unesdoc.unesco.org/images/0013/001394/139421e.pdf (16.04.2018).

4. Malagoli D., Ottaviani E. Yessotoxin affects fMLP-induced cell shape changes in Mytilusgalloprovincialis immunocytes. Cell. Biol. Int., 2004, vol. 28, no.1, pp. 57-61.

5. Alfonso A., Vieytes M.R., Botana L.M. Yessotoxin, a Promising Therapeutic Tool. Mar. Drugs., 2016, vol. 14, pp. 30. DOI: 10.3390/md14020030

6. Marine biotoxins in shellfish - Yessotoxin group. Scientific Opinion of the Panel on Contaminants in the Food chain (Question No EFSA-Q-2006-065D). The EFSA Journal, 2008, vol. 907, pp. 162. Available at: http://www.efsa.europa.eu/sites/default/files /scientific_output/files/main_documents/907.pdf (16.04.2018).

7. Franchini A., Malagoli D., Ottaviani E. Targets and Effects of Yessotoxin, Okadaic Acid and Palytoxin: A Differential Review. Mar. Drugs., 2010, vol. 8, pp. 658-677. DOI: 10.3390/md8030658

8. Korsnes M.S Apoptotic events by yessotoxin in myoblast cell lines from rat and mouse. Toxicol. in vitro, 2006, vol. 20, pp. 1077-1087.

9. Korsnes M.S., Korsnes R. Mitotic Catastrophe in BC3H1 Cells following Yessotoxin Exposure. Front. Cell. Dev. Biol., 2017, vol. 5, no. 30, 18 p. DOI: 10.3389/fcell.2017.00030

10. Marine biotoxins. Food and Nutrition Paper (80). Rome: Food and agriculture organization of the united nations, 2004, $287 \mathrm{p}$.

11. Regulation (EC) No 853/2004 of the European Parliament and of the Council of 29 April 2004. Official Journal of the European Union, 2004. Available at: https://eur-lex.europa.eu/LexUriServ/LexUriServ.do?uri=OJ:L:2004:139:0055:0205:EN:PDF (16.04.2018).

12. Commission Regulation (EU) No 786/2013 of 16 August 2013 amending Annex III to Regulation (EC) No 853/2004 of the European Parliament and of the Council as regards the permitted limits of yessotoxins in live bivalve mollusks. Official Journal of the European Union, 2013. Available at: 


\section{https://eur-lex.europa.eu/LexUriServ/LexUriServ.do?uri=OJ:L:2013:220:0014:0014:EN:PDF}

(16.04.2018).

13. Ohkawa H., Ohishi N., Yagi K. Assay for lipid peroxides in animal tissues by thiobarbituric acid reaction. Anal. Biochem., 1979, vol. 95, no. 2, pp. 351-358.

14. Razygraev A.V. Metod opredeleniya glutationperoksidaznoiaktivnosti $\mathrm{s}$ ispol'zovaniemperoksidavodoroda i 5,5'-ditiobis(2-nitrobenzoinoi kisloty) [A procedure for determining glutathione peroxidase activity with hydrogen peroxide and 5 5'-dithiobis(2-nitrobenzoic acid)]. Kliniko-laboratornyikonsilium, 2004, no. 4, pp. 19-22 (in Russian).

15. Raspopov R.V., Trushina E.N., Gmoshinsky I.V., Khotimchenko S.A. Biodostupnost' nanochastitsoksidazhelezapriispol'zovaniiikhvpitanii. Rezul'taty eksperimentov na krysakh [Bioavailability of nanoparticles of ferric oxide when used in nutrition. Experimental results in rats]. Voprosypitaniya, 2011, vol. 80, no. 3, pp. 25-30 (in Russian).

Bagryantseva O.V., Gmoshinskii I.V., Evstratova A.D., Trushina E.N., Mustafina O.K., Soto Kh.S., Shipelin V.A., Shumakova A.A, Panova A.D., Khotimchenko S.A. Toxicity of yessotoxin in experiment in vivo. Health Risk Analysis, 2018, no. 3, pp. 112-119. DOI: 10.21668/health.risk/2018.3.12.eng

Received: 08.05.2018

Accepted: 20.09 .2018

Published: 30.09 .2018 